\title{
ALTERATION OF SPORT PERFORMANCE OF HIGH PERFORMANCE HEPTATHLON ATHLETE OVER OLYMPIC CYCLE
}

\author{
Kazys Milašius, Juozas Skernevičius \\ Vilnius Pedagogical University, Vilnius, Lithuania
}

\begin{abstract}
Kazys Milašius. Professor, Doctor, Habil. of Biomedicine Sciences. Head of Sport Methodology Department of Vilnius Pedagogical University, Director of Sport Science Institute. The field of scientific research - athletes' organism adaptation to physical loads, methodology and management of athletes' training.
\end{abstract}

\begin{abstract}
In Lithuania, over the recent years a highly-skilled heptathlon athlete has been developed. She made her international debut in the Sidney Olympic Games in 2000 and took the $12^{\text {th }}$ place. Every year she kept improving her skills and excellently prepared for the XXVIII Olympic Games in Athens where she won a silver medal.

Track-and-field heptathlon requires excellent physical fitness, development of all specific features, as well as good physical fitness for each contest. While planning the process of a heptathlon athlete's training, it is most important to elaborate an optimum structure of an annual cycle with regard to the competition schedule and the individual potential of human adaptation. To be able to control the process, it is necessary to monitor the dynamics of the physical and functional abilities of the athlete in different periods of the annual cycle of training.

The aim of the study was to analyse the dynamics of sports results of the Lithuanian heptathlon athlete A. S. in a fouryear Olympic cycle and the dynamics of her physical and functional abilities over this period.

We analyzed the dynamics of the sports results of A. S. over the last five years. Her body composition indices were measured in laboratory, with determining psychomotor response time and movement frequency per $10 \mathrm{~s}$. To determine her physical abilities, we measured her single muscular contraction power (SMCP), anerobic alactic muscular power $(A A M P)$. A running-track was used to establish the intensity of energetic processes at the anaerobic threshold level, with measuring heart rate (HR), running speed $(\mathrm{km} / \mathrm{h})$ and blood lactate concentration. The functional capacity of the circulatory and respiratory systems was assessed by the Roufier index (RI). Anaerobic capacity was measured with a gas analyzer at the critical intensity and anaerobic metabolism limits.

The sports results of A. S. kept improving every year except 2003. In the 2004 Olympic Games she gathered 6435 points and won the second place. In previous years, in separate heptathlon contests the sum total of her points reached 12.7$15.6 \%$, whereas in the 2004 Olympic Games the difference among scores got in separate contests was less. Most points were won in the

100-m hurdling (15.1\%) and the least in javelin throwing (13.3\%).

Data of laboratory tests showed that the quality of the SMCP and AAMP indices, which are decisive in even five contests of heptathlon, over the four-year Olympic cycle showed a waved dynamics, but attained a high level one month before the Olympic start: her SMCP was $3.22 \mathrm{kgm} / \mathrm{s} / \mathrm{kg}$ and AAMP $1.72 \mathrm{kgm} / \mathrm{s} / \mathrm{kg}$. Also, greatly improved her psychomotor response time, which reached $160 \mathrm{mls}$, and central nervous system lability (78 movements per $10 \mathrm{~s}$ ). Her high muscular power was confirmed by performing ten jumps on a running-jumping track, when the difference between the highest and lowest jumps was insignificant and muscular fatigue in a series of jumps was low.

In the final period of the preparation for the Olympic Games under a short-lasting load the muscular power of A. S. reached a high level and allowed her to realize physical and functional abilities.
\end{abstract}

Keywords: heptathlon, four-year Olympic cycle, physical abilities, functional capacity, physical and functional abilities.

\section{INTRODUCTION}

I n Lithuania, over the recent years a highly skilled heptathlon athlete A. S. has been developed. She made a fine international debut in the Sydney Olympic Games in 2000, where she took the $12^{\text {th }}$ place. In the 2001 World Track-and-Field Championship she took the sixth place, won a bronze medal at the European
Championship of Youth under 23, and in 2002 took the fourth place in the 2002 European Championship. Her performance at the 2003 World Championship in Paris was not successful (the 10th place) (Milašius et al., 2003). In the subsequent year she improved considerably her technique in separate contests, developed her 
physical and functional abilities and at the XXVIII Olympic Games in Athens, took the second place.

Track-and-field heptathlon requires excellent physical fitness, development of each single specific physical ability (Комарова, 1985) and fine performance for each contest (Молодцов и др., 1985; Radžiukynas, 1997).

There are differences in training all-rounders and separate contest performers. Training for each contest takes comparatively little time. The training of heptathlon athletes is an integrated process, which requires bearing in mind that training for a separate contest or developing a separate ability may influence the abilities involved in another contest (Hauptmann, 1994; Radžiukynas ir kt., 2004; Streckis et al., 2005). While planning the training of heptathlon athlete it is most essential to compile the optimal annual cycle of training, in which the contest calendar, the individual possibilities of human adaptation, ability to technique fitness of separate septathlon techniques should be accounted for (Karoblis, 1985; Платонов, 1997).

A sportswoman has to develop individually her abilities in separate contests and the related physical performance. After several years of training it becomes evident that in some contests the indices are lagging behind, although the sum total of points keeps increasing. This lagging behind most often is predetermined by the genetic and functional abilities, long-term adaptation peculiarities (Немцова, 1991; Коті, 1992; Моногаров, 1994; Skurvydas et al., 1998).

Analysis of the long-term dynamics of the improving results if top-class world's all-rounders and their training load has shown that it is necessary to analyze the process of training of top-class heptathlon athlete and her physical and functional abilities over a four-year Olympic preparatory cycle.

At present, there is a shortage of research analyzing the organizational and methodical peculiarities of long-term training and separate training cycles of highly skilled heptathlon athletes, the dynamics of their results in an Olympic cycle and human adaptation to physical loads.

The aim of the current research was to analyze the dynamics of sports results of A. S. over a four year Olympic cycle and the dynamics of her physical and functional abilities reflecting her human adaptation over this period.

\section{METHODS}

The contest results, the dynamics of physical and functional parameters of highly skilled Lithuanian heptathlon athlete A. S. were analyzed over a four-year Olympic cycle while preparing for the Athens Olympic Games of 2004 (Raslanas et al., 2001). Extended investigations of the Sports Science Laboratory of Vilnius Pedagogical University were performed seven times: before the Sydney Olympic Games (2000), before the World Track-and-Field Championship (31 July 2001), before the European Championship (5 July 2002), before the World Championship (23 December 2002, 13 August 2003) and before the Athens Olympic Games (4 June 2004, 16 July 2004). Laboratory tests included body composition indices, such as body mass, lung volume (LV), muscle and fat mass and their ratio (MFMI), as well as psychomotor response time (PRT), movement frequency per $10 \mathrm{~s}$. Testing physical abilities involved single muscular contraction power (SMCP), anaerobic alactic muscular power (AAMP). A.S. underwent a ten-jump test on an jump and running meter with measuring the height and power of each jump. The intensity of energetic processes at the anaerobic metabolism threshold, heart rate, running speed $(\mathrm{km} / \mathrm{h})$ and lactate level in peripheral blood were assured by using a running-track.

The functional ability of the circulatory and respiratory systems was assessed by the Roufier index (RI), heart rate at rest, response to an orthostatic test, standard physical load and at recovery. A gas analyzer was used to measure aerobic capacity by gradually increasing the load up to the critical intensity level. On reaching the critical intensity and anaerobic metabolism threshold limit, lung ventilation (LV), heart rate (HR), oxygen uptake $\left(\mathrm{VO}_{2 \max }\right)$, oxygen pulse (OP), work power (W), work efficiency (oxygen uptake for $1 \mathrm{~W}$ of work) were established.

\section{RESULTS}

The heptathlon athlete's results kept improving every year. In 2000, at the Olympic Games, A. S. took the $12^{\text {th }}$ place and gathered 6021 points. In 2000, at the World Track-and-Field Championship in Edmonton (Canada) she got 6112 points and took the $6^{\text {th }}$ place. In 2002, at the European Championship, A.S. won the $4^{\text {th }}$ place and collected 
Table 1. Sports results' dynamics of highly-skilled heptathlon athlete A. S. in 2000-2004
Table 2. Characteristics of ten jumps performed by highly-skilled heptathlon athlete A. S. on jumpmeter

\begin{tabular}{|c|c|c|c|c|c|c|c|c|c|c|}
\hline \multirow{2}{*}{$\begin{array}{l}\text { Event, date, } \\
\text { place, number } \\
\text { of finishing } \\
\text { participants }\end{array}$} & \multirow[b]{2}{*}{$\begin{array}{c}\text { Results' } \\
\text { characteristics }\end{array}$} & \multicolumn{7}{|c|}{ Contests } & \multirow[b]{2}{*}{$\begin{array}{l}\text { Total } \\
\text { place }\end{array}$} & \multirow[b]{2}{*}{$\begin{array}{l}\text { Total } \\
\text { points }\end{array}$} \\
\hline & & $\begin{array}{c}100 \mathrm{~m} \\
\text { hurdling, } \\
\mathrm{s}\end{array}$ & $\begin{array}{c}\text { High } \\
\text { jump, } \\
\text { m }\end{array}$ & $\begin{array}{c}\text { Shot } \\
\text { put, } \\
\text { m }\end{array}$ & $\begin{array}{c}200 \mathrm{~m}, \\
\mathrm{~s}\end{array}$ & $\begin{array}{c}\text { Long } \\
\text { jump, } \\
\text { m }\end{array}$ & $\begin{array}{l}\text { Javelin } \\
\text { throwing, } \\
\mathrm{m}\end{array}$ & $\begin{array}{l}800 \mathrm{~m} \\
\min \end{array}$ & & \\
\hline \multirow{4}{*}{$\begin{array}{l}\text { XXVII } \\
\text { Olympic } \\
\text { Games, } \\
\text { Sidney, } \\
23- \\
2409 \text { 2000, } \\
33 \text { participants }\end{array}$} & Result & 14.37 & 1.78 & 15.09 & 25.35 & 5.97 & 45.43 & 2.20 .25 & \multirow{4}{*}{12} & \multirow{4}{*}{6021} \\
\hline & $\begin{array}{l}\text { Total points } \\
\text { in contest }\end{array}$ & 927 & 953 & 867 & 855 & 840 & 772 & 820 & & \\
\hline & $\begin{array}{l}\% \text { in } \\
\text { heptathlon }\end{array}$ & 15.4 & 15.8 & 14.4 & 14.2 & 13.9 & 12.8 & 13.6 & & \\
\hline & $\begin{array}{l}\text { Place in } \\
\text { contest }\end{array}$ & 27 & $\frac{8-}{12}$ & 2 & $\begin{array}{c}19- \\
20\end{array}$ & 14 & 8 & 22 & & \\
\hline \multirow{4}{*}{$\begin{array}{l}\text { World Track- } \\
\text { and-Field } \\
\text { Championship, } \\
\text { Edmonton, } \\
04- \\
0508 \text { 2001, } \\
18 \text { participants }\end{array}$} & Result & 14.37 & 1.79 & 16.06 & 25.52 & 6.00 & 46.12 & 2.20 .78 & \multirow{4}{*}{6} & \multirow{4}{*}{6112} \\
\hline & $\begin{array}{l}\text { Total points } \\
\text { in contest }\end{array}$ & 927 & 966 & 932 & 840 & 850 & 784 & 813 & & \\
\hline & $\begin{array}{l}\% \text { in } \\
\text { heptathlon }\end{array}$ & 15.2 & 15.8 & 15.3 & 13.7 & 13.9 & 12.8 & 13.3 & & \\
\hline & $\begin{array}{l}\text { Place in } \\
\text { contest }\end{array}$ & 13 & $5-8$ & 1 & 11 & 7 & 7 & 10 & & \\
\hline \multirow{4}{*}{$\begin{array}{l}\text { European } \\
\text { Track-and- } \\
\text { Field } \\
\text { Championship, } \\
\text { Munich, } \\
05- \\
0607 \text { 2002, } \\
24 \text { participants }\end{array}$} & Result & 14.08 & 1.80 & 16.72 & 25.01 & 6.14 & 46.72 & 2.23 .38 & \multirow{4}{*}{4} & \multirow{4}{*}{6275} \\
\hline & $\begin{array}{l}\text { Total points } \\
\text { in contest }\end{array}$ & 967 & 978 & 976 & 886 & 893 & 797 & 778 & & \\
\hline & $\begin{array}{l}\% \text { in } \\
\text { heptathlon }\end{array}$ & 15.4 & 15.6 & 15.6 & 14.1 & 14.2 & 12.7 & 12.4 & & \\
\hline & $\begin{array}{l}\text { Place in } \\
\text { contest }\end{array}$ & 16 & $4-8$ & 1 & 1 & 9 & 7 & 14 & & \\
\hline \multirow{4}{*}{$\begin{array}{l}\text { World Track- } \\
\text { and-Field } \\
\text { Championship, } \\
\text { Paris, } \\
23- \\
24082003 \text {, } \\
22 \text { participants }\end{array}$} & Result & 14.44 & 1.76 & 16.35 & 25.76 & 5.86 & 47.57 & 2.18 .64 & \multirow{4}{*}{10} & \multirow{4}{*}{6077} \\
\hline & $\begin{array}{l}\text { Total points } \\
\text { in contest }\end{array}$ & 917 & 928 & 952 & 818 & 807 & 813 & 842 & & \\
\hline & $\begin{array}{l}\% \text { in } \\
\text { heptathlon }\end{array}$ & 15.0 & 15.3 & 15.7 & 13.6 & 13.2 & 13.4 & 13.8 & & \\
\hline & $\begin{array}{l}\text { Place in } \\
\text { contest }\end{array}$ & 21 & $\begin{array}{c}10- \\
18\end{array}$ & 2 & 20 & 16 & 6 & 15 & & \\
\hline \multirow{4}{*}{$\begin{array}{l}\text { XXVIII } \\
\text { Olympic } \\
\text { Games, } \\
\text { Athens, } \\
20- \\
2108 \text { 2004, } \\
26 \text { participants }\end{array}$} & Result & 14.03 & 1.76 & 16.40 & 24.82 & 6.30 & 49.58 & 1.15 .92 & \multirow{4}{*}{2} & \multirow{4}{*}{6435} \\
\hline & $\begin{array}{l}\text { Total points } \\
\text { in contest }\end{array}$ & 974 & 928 & 955 & 903 & 943 & 852 & 882 & & \\
\hline & $\begin{array}{l}\text { \% in } \\
\text { heptathlon }\end{array}$ & 15.1 & 14.4 & 14.8 & 14.0 & 14.7 & 13.3 & 13.7 & & \\
\hline & $\begin{array}{l}\text { Place in } \\
\text { contest }\end{array}$ & 24 & $\begin{array}{l}14- \\
17\end{array}$ & 1 & 16 & 7 & 3 & 14 & & \\
\hline
\end{tabular}

\begin{tabular}{|c|c|c|}
\hline Indices $\quad$ Testing date & 04062004 & 16072004 \\
\hline Total height, $\mathrm{cm}$ & 414.7 & 398.5 \\
\hline 10 jump mean, $\mathrm{cm}$ & 41.5 & 39.5 \\
\hline Max. jump, cm & 45.1 & 43.8 \\
\hline Min. jump, cm & 39.1 & 34.2 \\
\hline 10 jump power mean, $\mathrm{W} / \mathrm{kg}$ & 41.5 & 38.7 \\
\hline Push off mean, $\mathrm{s}$ & 0.197 & 0.203 \\
\hline Flight mean, s & 0.583 & 0.570 \\
\hline
\end{tabular}

6275 points. In the 2003 World Championship in Paris A.S. failed to improve her result: with her 6077 points she took only the tenth place (Table 1). However, the same year in another contest she covered the A level qualifying result which allowed her participation at the Athens Olympic Games. After a year, at these Games, A.S. reached her personal record (6435 points), took the second place and won a silver medal.

Analysis showed that the contribution of separate contests to the total result was uneven. According to the points collected in 2000-2003, all the seven contests can be divided into three groups. The first group comprises the $100-\mathrm{m}$ hurdling, high jump and shot put (15.0-15.8\% of the total points). The second group includes $200 \mathrm{~m}$ and long jump contest $(13.7-14.2 \%$ of the total points). The third group embraces javelin throwing and $800 \mathrm{~m}$ running (12.4 and $13.6 \%$ ). However, in 2004 this distribution underwent changes. The difference among the points gathered in different contest decreased. The first group included high jump, hurdling, shot put and long jump which furnished $15.1-14.4 \%$ of the total heptathlon 
Table 3. Dynamics of aerobic capacity indices of highly-skilled heptathlon athlete A. S. in 2000-2003

\begin{tabular}{|c|c|c|c|c|c|c|c|c|c|c|c|c|c|c|c|}
\hline \multirow{2}{*}{ Testing date } & \multicolumn{7}{|c|}{ Critical intensity limit } & \multicolumn{8}{|c|}{ Anaerobic threshold limit } \\
\hline & $\begin{array}{l}\mathrm{LV} \\
1 / \mathrm{min}\end{array}$ & $\begin{array}{l}\mathrm{HR}, \\
\mathrm{b} / \mathrm{min}\end{array}$ & $\begin{array}{l}\mathrm{VO}_{2} \\
1 / \mathrm{min}\end{array}$ & $\begin{array}{c}\mathrm{VO}_{2}, \\
\mathrm{ml} / \mathrm{min} / \mathrm{kg}\end{array}$ & $\begin{array}{l}\mathrm{OP} \\
\mathrm{ml} / \mathrm{t}\end{array}$ & W & $\begin{array}{c}\mathrm{O}_{2} \\
\mathrm{ml} / 1 \mathrm{~W}\end{array}$ & $\begin{array}{l}\mathrm{LV} \\
1 / \min \end{array}$ & $\begin{array}{l}\mathrm{HR}, \\
\mathrm{b} / \mathrm{min}\end{array}$ & $\begin{array}{l}\mathrm{VO}_{2} \\
1 / \mathrm{min}\end{array}$ & $\begin{array}{c}\mathrm{VO}_{2}, \\
\mathrm{ml} / \mathrm{min} / \mathrm{kg}\end{array}$ & $\begin{array}{l}\mathrm{OP} \\
\mathrm{ml} / \mathrm{t}\end{array}$ & $\begin{array}{l}\mathrm{O}_{2} \% \\
\text { from } \\
\mathrm{VO}_{2} \\
\max \end{array}$ & W & $\begin{array}{c}\mathrm{O}_{2}, \\
\mathrm{ml} / 1 \mathrm{~W}\end{array}$ \\
\hline 07062000 & 113.3 & 186 & 3.70 & 47.5 & 18.0 & 260 & 14.2 & 71.3 & 160 & 2.71 & 34.7 & 16.9 & 73.2 & 220 & 12.3 \\
\hline $05072002 *$ & 98.0 & 172 & 2.86 & 35.3 & 16.6 & 280 & 10.2 & 80.4 & 158 & 2.62 & 32.3 & 16.2 & 91.6 & 250 & 10.5 \\
\hline 13082003 & 118.2 & 183 & 3.14 & 38.8 & 17.1 & 290 & 10.8 & 76.8 & 162 & 2.44 & 30.1 & 14.5 & 77.0 & 250 & 9.76 \\
\hline
\end{tabular}

Note.* - A.S. did not reach critical intensity limit in test performed 5 July 2002.
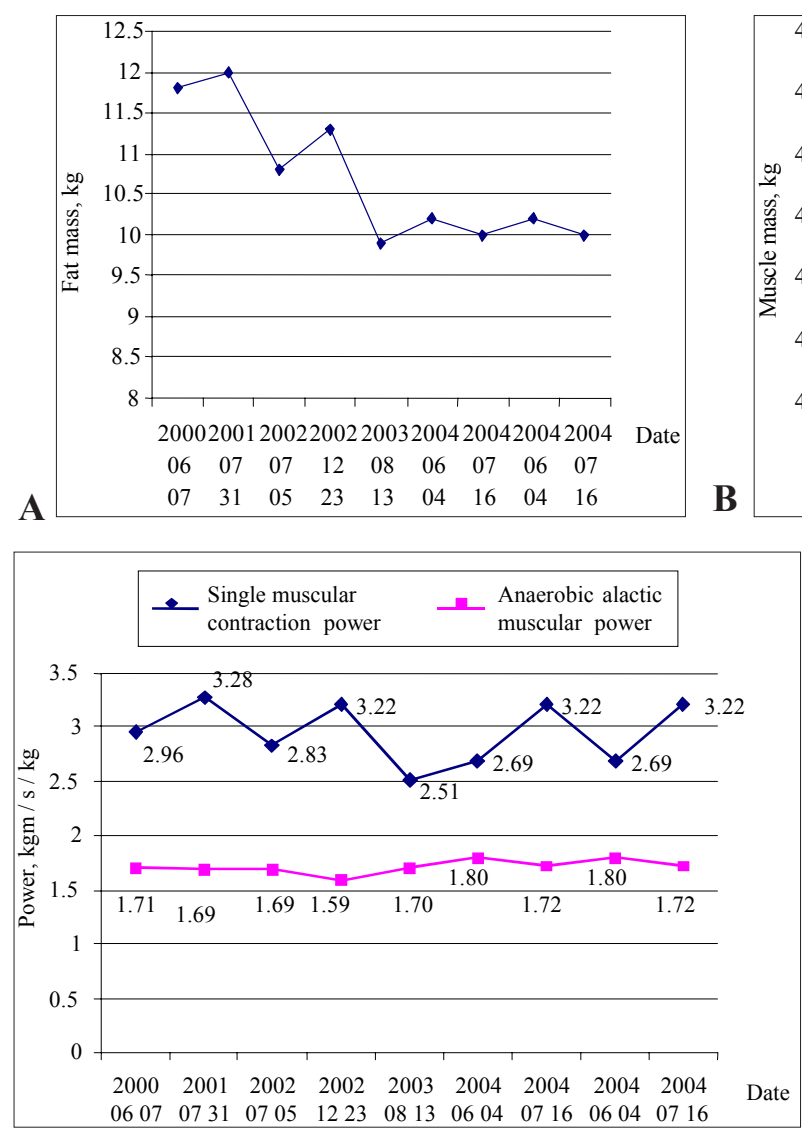

Fig 2. Dynamics of single muscular contraction power and anaerobic alactic muscular power indices of highly-skilled heptathlon athlete A. S. in 2000-2004

points. The second group comprised $200 \mathrm{~m}$ and 800 $\mathrm{m}$ running and javelin throwing $(14.0-13.3 \%$ of the total points) (Table 1).

The results of most contests, except high jump and putting the shot were better than in previous years. In 2004 a particular improvement was shown in javelin throwing, 100-m hurdle-race, 800-m running, long jump, in which A. S. improved her personal results. However, she should increase her anaerobic glycolytic and aerobic capacity, although more time dedicated to developing aerobic capacity may reduce muscular contraction power and speed.

Data of laboratory tests showed an uneven dynamics of the body composition indices of A. S. Her body mass in 2001 reached $85.0 \mathrm{~kg}$, the

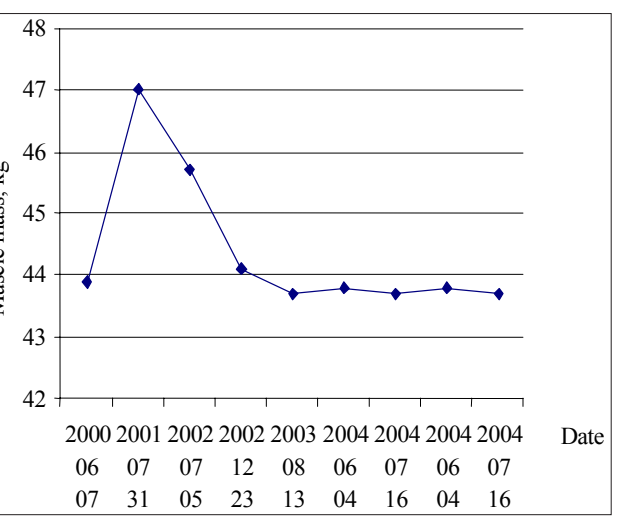

Fig. 1. Dynamics of muscle (A) and fat mass (B) indices of h i g h l y - s kill e d heptathlon athlete A. S. in 2000-2004

muscular and fat mass being also highest. The conclusion was that these body mass indices were too high; therefore A. S. reduced her body mass by next season (Fig. 1).

In many of heptathlon contest, single muscular contraction and anaerobic alactic muscular power indices are of great importance. Even in five heptathlonic contests the quality of these indices is partially decisive for the final result. A.S. developed a rather high SMCP (above $3.00 \mathrm{kgm} /$ $\mathrm{s} / \mathrm{kg}$ ). On the eve of the 2003 World Championship it was too low $(2.51 \mathrm{kgm} / \mathrm{s} / \mathrm{kg})$. However, a year later, one month before the Olympic Games, it returned to the former level. The AAMP index over the study period was rather stable; however, it should be improved if higher results are desirable (Fig. 2). The PRT was lowest in 2002, reaching $149 \mathrm{mls}$ - a very high index. Before the Olympic Games it reached $160 \mathrm{mls}$.

In 2004, a ten-jump test was included into the testing program of $\mathrm{A}$. S. It was performed on an SBM-1 jumping and running meter. The test results were obtained 2.5 and 1 months before the Olympic Games. All muscular power indices were higher in June than in July (Table 2).

The intensity of bioenergetic processes at the anaerobic metabolism threshold and critical intensity levels was indicative of the aerobic capacity of A. S. To determine the anaerobic metabolism threshold, the track running speed, PR and blood lactate concentration were measured. 
The running speed of A. S. at this limit varied between 7.0 and $11 \mathrm{~km} / \mathrm{h}$, and in 2004, 10 months before the Olympic Games, her running speed at the anaerobic metabolism threshold was $7.0 \mathrm{~km} / \mathrm{h}$, HR being $165 \mathrm{~b} / \mathrm{min}$ and blood lactate level $-5.2 \mathrm{mmol} / 1$.

The aerobic capacity of A. S. at the critical intensity level over three years made an insignificant progress. First of all it was related to body mass increase. The highest $\mathrm{VO}_{2 \max }(47.5 \mathrm{ml} /$ $\mathrm{kg}$ ) was fixed in 2000 (Table 3). In 2002, oxygen consumption fell down to $35.3 \mathrm{ml} / \mathrm{kg}$. However, in 2002 the working efficiency of A. S. at critical intensity and anaerobic metabolism threshold limits was rather high, taking $10.2-10.5 \mathrm{ml}$ oxygen per $1 \mathrm{~W}$. The increasing potential of her aerobic abilities at the critical intensity limits is shown also by a high relative oxygen uptake at the anaerobic metabolism threshold (it reached 91.6\% of $\mathrm{VO}_{2 \max }$ ). In $2003, \mathrm{VO}_{2 \max }$ increased to $38.8 \mathrm{ml} /$ $\mathrm{kg}$, and at the anaerobic metabolism threshold limit oxygen uptake was $30.1 \mathrm{ml} / \mathrm{kg}$ (77\% of $\mathrm{VO}_{2 \max }$ ). In 2004, her aerobic capacity increased even more, allowing A. S. to improve her result in 800 -m running.

\section{DISCUSSION}

Heptathlon is one of the most difficult women's track-and-field competitions. Its final result depends on a good performance in all heptathlonic contests. Most authors (Комарова, 1985; Hauptmann, 1994; Моногаров, 1994) claim that heptathlon cannot be regarded as as mere sum of separate track-and-field contest results. In the opinion of many authors (Bosco, 1982; Немцова, 1991), results in heptathlon first of all depend on the well developed muscular power under a short-term load. Even five heptathlonic contest require high anaerobic alactic muscular power, one contest requires mixed anaerobic alactic glycolytic capacity, and the last one, 800-m running, requires a high anaerobic glycolytic and aerobic capacity. A.S. has been showing the highest points in three contests - 100-m hurdling, high jump and shot put. Her javelin throwing and $800-\mathrm{m}$ running results have been poorer. At the 2003 World Championship in Paris A. S. performed not too well. The unsatisfactory result was predetermined by a poorer performance in the contests in which she had been showing much better results (Milašius et al., 2003). At the Athens Olympic Games A. S. managed to improve personal results in three contests and to balance the number of points won in each contest.

Laboratory tests show that A. S.'s body mass, fat in particular, is too high. However, her muscular contraction power under anaerobic alactic energy production is rather high. Her psychophysiological state indices correspond to her muscular power. In P. Komi's opinion (1992), these indices are very important while developing speed and force, as they are a constituent part of agility. As one of the most objective methods of determining muscular power, a maximum strain ten-jump test can be applied, its data show muscular strength endurance. The annual testing of aerobic capacity does not show a pronounced progress in the aerobic capacity of A. S. Her aerobic endurance, which is essential in $800-\mathrm{m}$ running, though improved in 2004, is not yet sufficient.

\section{CONCLUSIONS}

1. A. S., the highly skilled heptathlon athlete from Lithuania, is one of the world's best athletes that performed well at the Athens Olympic Games. Over the recent five years her skills have been growing, however, in the 2003 World Championship she failed to improve her result and won the $5^{\text {th }}-6^{\text {th }}$ place. Supposedly this was a methodological flaw in the final microcycle of training for the World Championship.

2. In 2002-2003, the heptathlonic contests of A. S. by points were divided into three groups. The first group comprised contests in which A. S. wins more than $15 \%$ of all heptathlon points, i. e. 100-m hurdle-race, high jump, putting the shot. The second group included contests that provided $14 \%$ of points each 200 $\mathrm{m}$ running and high jump. The third group consisted of the two backward contests javelin throwing and $800-\mathrm{m}$ running, which provided less than $13 \%$ each. The future progress of A. S. is most probable in javelin throwing, in which the result greatly depends on rapid muscular contraction and the biomechanics of movement performance. However, in 2004 there became evident a new variant of the contest assessment by points: the 
first group comprised the contests in which A. S. wins $14.4-15.1 \%$ of points (hurdling, high jump, shot put, long jump), and the second group embraces those providing 13.3-14.0\% of points $(200-\mathrm{m}$ and $800-\mathrm{m}$ running and javelin throwing).

3. The physical and functional abilities of A. S. over the study period have been clearly increased. Her muscular power under a shortterm load is sufficiently high, though in separate years of the Olympic cycle it showed an uneven dynamics. The physical and functional capacity of A. S. was improving according to researchers' recommendations (while reducing the body mass to increase muscular contraction force, to improve the psychomotor response rate).

Following a certain stabilization of these indices in 2003, after one year they improved again, allowing A. S., even in three contests from seven, to improve her personal results and to show sufficiently high results in other contests.

\section{REFERENCES}

Bosco, C. (1982). Physiological considerations of strength and explosive power and jumping drills. Proceedings Planning for Elite Performance. Ottawa. P. 20-34.

Hauptmann, M. (1994). Training of schnelligkeit. Trainings - Wissenschaft. Berlin: Sportverlag. P. 339347.

Karoblis, P. (1985). Lengvoji atletika. Vilnius: Mintis.

Komi, P. (1992). Strength and Power in Sport. Blackwell Scientific Publications. New York.

Milašius, K., Skernevičius, J., Sakalys, V. (2003). Didelio meistriškumo septynkovininkès sportinių rezultatų ir fizinių galių kaita per keturmetị olimpinį ciklą. Ugdymas. Küno kultūra. Sportas, 5 (50), 38-43.

Radžiukynas, Dr., Radžiukynas, Dn., Žilinskienė, N. (2004). Lengvaatlečių trumpujų nuotolių bėgikų ir šuolininku specialusis fizinis parengtumas. Ugdymas. Kūno kultūra. Sportas, 3 (53), 29-36.

Radžiukynas, D. (1997). Trumpu nuotoliu bègimo ir šuoliu treniruočiu teorija ir didaktika.

Raslanas, A. ir kt. (2001). Programa „Atènai - 2004“. Vilnius.
Skurvydas, A., Stanislovaitis, A., Mamkus, G. (1998). Didelio meistriškumo sportininkų raumenų susitraukimo savybiu kitimas kas $30 \mathrm{~s}$ atliekant tris serijas po 10 šuoliu maksimaliu intensyvumu. Sporto mokslas, 5 (14), 83-85. Streckis, V., Butkus, V., Radžiukynas, D., Gorianovas, G. (2005). Lietuvos lengvosios atletikos moterų daugiakovès rinktinès sportinių rezultatų kaita Europos taurès varžybose 1999-2003 m. Sporto mokslas, 1 (39), 4852.

Комарова, А. (1985). Учёные - многоборцам. Лёгкая атлетика, 8, 4-6.

Молодцов, И., Михайлов, В., Ребзон, А. (1985). Модели семиборья. Лёгкая атлетика, 12, 6-7.

Моногаров, В. Д. (1994). Генез утомления при напряжённой мышечной деятельности. Наука 8 олимпийском спорте, 1, 47-57.

Немцова, Н. А. (1991). Специиальная силовая подготовка в женском легкоатлетическом многоборье: афтореферат дисс. Москва.

Платонов, В. (1997). Общая теория подготовки спортсменов в олимпийском спорте. Киев: Олимпийская литература.
Received on May 2, 2005

Accepted on June 30, 2005
Kazys Milašius

Vilnius Pedagogical University Studentu str. 39, LT-08106 Vilnius Lithuania

$\mathrm{Tel}+37052734858$

E-mail kazys.milasius@vpu.lt 